\title{
PROSPEK PARTISIPASI PETAN I DALAM PROGRAM PEMBANGUNAN HUTAN RAKYAT UNTUK MITIGASI PERUBAHAAN IKLIM DI WONOSOBO
}

\section{The Prospect of Farmers' Participation in the Development Program of Farm Forestry for Climate C hange Mitigation in Wonosobo}

\author{
Evi Irawan \\ Balai Penelitian Kehutanan Solo, \\ E-mail: evirawan17@yahoo.com
}

\begin{abstract}
ABST RACT
Past experienes indicate that the surcess of many famforestry projets is mainly influeneed by farmes' participation Ex ante estimation of the likdihood of famms' partiapation in a partiallar fam foretry projet might reelure thenisk of proet failure This artideis to analyze, $\mathrm{ex}$ ante, factors affeetinga farme's partiapation in a hypothetical fam forestry projet for dimate dange mitigation based upon a survey data of 117 farm forestry farmess in Tempurgo Village, Wonosdbo Regenny. Logit estimation suggests that thelikelihood of a farme's partiapation is likdy affeted by age of farmer, education, farm houshdd size and famm's experiene in farmforestry business Tho pdices implication of these find ings are that gremment should inrease fames' knowkedge of dimate dange thraugh extension progams such as dimate fiedd schod, and align the design of farm forestry projets for dimate hange mitigation with the prevailing fam forestry managenet system pradiced by famess
\end{abstract}

Keywords: farmers' participation, farm forestry, climate change mitigation

\begin{abstract}
ABST RAK
Pengalaman masa lalu mengindikaskan bahma kebehasilan berbagai proyk perbangunan hutan rakyat sangat ditentukan deh partisipas petari. Estimas $\mathrm{e}$ antetehadap besamya peduang partisipasi petani dalam suatu proyd hutan rakjat stidaknya dapat mengurang keegaglan projk. Artikd ini betujuan untuk menganalisis seara $e x$ ante faktorfaktor yang mempenganuhi keputusan ptani dalam berpartispasi dalam suatu proydk hutan rakyat hipottik untuk mitigasi perubahaan iklim dangan mengunakan data surve 117 arang patani hutan rakyat di Desa Tempurgo Kabupaten Wonosdbo Hasil estimas dengan mengunakan modd logit menujukkan bahma pduangpartisipas ptani cendaung dpenganuhi deh umr, penddikan, junlah anggta kduarga dan penglammn ptani dalammdakukan usaha hutan rakjat. Implikas kedjakan dari teman penditian ini meliputi dua hal, yakri pedurya peringkatan pengtahuan petani tertang perubahan iklimmialui progamprogram peryuluhan, sepeti skkdah lapang perubahan iklim dan pelunya merydaraskan rancangan projk hutan rakyat dengan sistem pengldaan hutan rakyat yang bekkenkang di masyarakat.
\end{abstract}

Kata kunci: partisipasi petani, hutan rakyat, mitigasi perubahan iklim 


\section{PEN DAH ULUAN}

Pada konferensi tingkat tinggi (KTT) perubahan iklim di Kopenhagen tahun 2009 pemerintah Indonesia telah berkomitmen untuk mengurangi emisi karbon sebesar 26\% pada tahun 2020. Salah satu opsi yang dapat dilakukan untuk mencapai komitmen tersebut adalah melalui program reboisasi dan penghijauan, misalnya pembangunan hutan rakyat, pada lahan-lahan kritis yang tersebar merata hampir di seluruh pulau di Indonesia. D ata statistik kehutanan tahun 2008 mencatat bahwa luas lahan kritis tahun 2007 telah mencapai lebih dari 77 juta hektar (D epartemen Kehutanan, 2009). Hasil perhitungan Balai Pemantapan Kawasan Hutan (BPKH) Wilayah XI Jawa-Madura dan Multistakehdder Forestry Programme (2009) mengindikasikan bahwa hutan rakyat di Pulau Jawa dan Madura mampu menyimpan karbon lebih dari 40 juta ton. Selain itu, mitigasi perubahan iklim melalui program-program kehutanan memiliki keunggulan dalam hal efektifitas biaya dan berpeluang besar memberikan dampak ikutan yang berupa peningkatan kualitas lingkungan, peningkatan pendapatan masyarakat sekitar dan dalam kawasan hutan, dan meningkatkan keanekaragaman hayati.

Sejak awal dekade 1990-an hutan rakyat telah mampu memasok kayu untuk memenuhi kebutuhan industri perkayuan. Rimbawanto (2008) bahkan mensinyalir bahwa hutan rakyat berpeluang besar menggantikan posisi hutan alam dalam memenuhi kebutuhan kayu industri pengolahan hasil hutan, di samping itu, pengembangan hutan rakyat juga dapat mewujudkan devisa melalui pencanangan ekowisata berbasis partisipasi masyarakat (Hayati, 2010). Seiring dengan semakin mengemukanya masalah perubahan iklim global yang juga berdampak pada kehidupan masyarakat pedesaan pada umumnya, pengelolaan hutan rakyat tampaknya perlu diarahkan tidak hanya untuk memenuhi kebutuhan kayu, tetapi juga untuk mitigasi perubahan iklim, khususnya dalam hal penyerapan karbon. Sebagai implikasinya adalah bahwa pengelolaan hutan rakyat perlu untuk disesuaikan sedemikian rupa sehingga dapat sejalan dengan program-program mitigasi perubahan iklim.

Karena hutan rakyat dikembangkan di atas tanah yang dibebani hak atas tanah dan petani merupakan pihak yang paling merasakan dampak sekaligus penentu akhir atas keberhasilan atau kegagalan proyek tersebut, maka partisipasi petani hutan rakyat dalam mitigasi perubahan iklim menjadi satu hal yang sangat dibutuhkan. Pengalaman di masa lampau menunjukkan bahwa kegagalan program-program pembangunan pedesaan salah satunya disebabkan oleh rendahnya partisipasi masyarakat desa, khususnya petani (Gombe, 1985).

Analisis ex ante partisipasi petani setidaknya dapat memberikan gambaran bagi pembuat kebijakan (pemerintah) tentang peluang kegagalan atau keberhasilan suatu proyek kehutanan. Jika hasil analisis menunjukkan tingkat partisipasi petani yang masih rendah, maka masih ada ruang dan waktu bagi pembuat kebijakan untuk memodifikasi atau membenahi rancangan proyek sedemikian rupa sehingga dapat diterima oleh masyarakat, khususnya petani. Proyek kehutanan yang dirancang berdasarkan kondisi sosial ekonomi masyarakat setidaknya dapat meningkatkan peluang keberhasilannya. Artikel ini bertujuan untuk mengestimasi secara ex ante faktor-faktor yang mempengaruhi partisipasi petani dalam proyek hutan rakyat untuk mitigasi perubahan iklim. 


\section{Kerangka Konseptual}

\section{Keputusan Berpartisipasi}

Dalam pustaka ilmu-ilmu sosial dan ekonomi terdapat beragam konsep partisipasi yang ditawarkan oleh para ahli; dari kata lain untuk mobilisasi sampai konsep pilihan tindakan berdasarkan kesadaran sendiri. Namun, tanpa mengurangi makna dari perdebatan tersebut, penelitian ini mendefinisikan partisipasi sebagai bentuk keterlibatan dan keikutsertaan masyarakat secara aktif dan sukarela, baik karena alasan-alasan dari dalam dirinya maupun dari luar dirinya dalam keseluruhan proses kegiatan yang bersangkutan.

Menurut teori ekonomi, terutama ekonomi neoklasik, manusia merupakan makhluk rasional yang bertindak atas dasar perhitungan manfaat yang akan diperoleh dan biaya yang harus dikeluarkan dengan mengacu pada kendala sumber daya yang dimilikinya. Lebih lanjut, teori ekonomi neoklasik beranggapan bahwa setiap individu memiliki preferensi atas sejumlah barang dan jasa dan terlepas dari biayanya, setiap individu mampu mengurutkan barang dan jasa berdasarkan preferensinya. A tas dasar pandangan seperti ini, partisipasi petani dalam suatu kegiatan atau proyek merupakan suatu bentuk perwujudan dari besarnya penilaian petani atas keuntungan dibandingkan dengan biaya yang harus dia keluarkan. Partisipasi diprediksikan akan terus berlanjut selama petani merasa puas atau diuntungkan dengan ikut serta dalam kegiatan tersebut. Misalkan bahwa utilitas seorang petani $i$ merupakan fungsi dari manfaat atau keuntungan yang dia peroleh dari usaha hutan rakyat dan dapat dituliskan sebagai $v_{0 i}\left(m_{i}, \mathbf{s}_{i}\right), m$ adalah manfaat atau keuntungan yang diperoleh petani dari usaha hutan rakyat dan $\mathbf{s}$ merupakan vektor karakteristik petani dan lahan. Jika petani tersebut berpartisipasi dalam proyek hutan rakyat untuk mitigasi perubahaan iklim, maka fungsi utilitas akan menjadi $v_{1 i}\left(m_{i}+\Delta m_{i}, \mathbf{s}_{i}\right) \cdot \Delta m$ menunjukkan perubahan manfaat atau keuntungan yang dapat diperoleh petani jika ikut serta dalam proyek mitigasi perubahan iklim. D engan menggunakan kerangka randomutility maximization (RUM) keputusan seorang petani untuk berpartisipasi, $\operatorname{Pr}(a=1)$, kemungkinan besar akan terjadi jika:

$$
\begin{aligned}
\operatorname{Pr}(a=1) & =\operatorname{Pr}\left\{v_{1 i}\left(m_{i}+\Delta m_{i}, \mathbf{s}_{i}\right)+\varepsilon_{1 i}>v_{\alpha i}\left(m_{i}, \mathbf{s}_{i}\right)+\varepsilon_{0_{i}}\right\} \\
& =\operatorname{Pr}\left\{\left(\varepsilon_{1 i}-\varepsilon_{\alpha i}\right)>-\left[v_{1 i}\left(m_{i}+\Delta m, \mathbf{s}_{i}\right)-v_{\alpha}\left(m_{l}, \mathbf{s}_{i}\right)\right]\right\}
\end{aligned}
$$

Jika $\left(\varepsilon_{1 i}-\varepsilon_{0 i}\right)$ digantikan dengan notasi $\varepsilon_{i} \operatorname{dan}\left[v_{1 i}\left(m_{i}+\Delta m_{i}, \mathbf{s}_{i}\right)-v_{0 i}\left(m_{i}, \mathbf{s}_{i}\right)\right]$ digantikan dengan notasi $\Delta v_{i}$, maka persamaan (1) selanjutnya dapat dituliskan menjadi

$\operatorname{Pr}(a=1)=\operatorname{Pr}\left(\varepsilon_{i}>-\Delta v_{i}\right)=\mathrm{F}_{\varepsilon_{i}}\left(\Delta v_{i}\right)$

$\mathrm{F}_{\varepsilon}(\Delta v)$ adalah ammlative distribution func tion (cdf) $\varepsilon_{i}$ yang dapat diasumsikan berdistribusi logistik atau normal dengan rerata nol dan ragam 1 . Tidak ada alasan apriori yang mendasari bahwa asumsi logistik lebih baik dari asumsi normal atau sebaliknya (G reene, 2003).

D engan mempertimbangkan bahwa keputusan seorang petani untuk ikut serta dalam proyek hutan rakyat untuk mitigasi bencana adalah biner (ya atau tidak), maka bentuk fungsional dari $\mathrm{F}_{\varepsilon_{i}}(\Delta v)$ dapat dispesifikasikan sebagai model logitatau prdait.

\section{Faktor-faktor yang Berpengaruh terhadap Partisipasi}

Portes (1971) menyatakan bahwa perbedaan tingkat partisipasi di kalangan 
petani dalam suatu program atau proyek kehutanan dapat dilihat dari latar belakang sosial ekonomi dan demografinya. Penelitian-penelitian terdahulu telah mengidentifikasikan beberapa faktor yang diduga berpengaruh terhadap partisipasi petani dalam kegiatan kehutanan, khususnya rehabilitasi sumber daya hutan dan lahan (SD HL). Faktor-faktor tersebut antara lain adalah pendidikan, umur, penguasaan lahan dan pekerjaan off-fam

Beberapa peneliti (misalnya: Lise, 2000; $\mathrm{G}$ lendinning \& al., 2001; O wubah \& al., 2001) menemukan bahwa tingkat pendidikan petani berpengaruh nyata terhadap keputusan petani untuk berpartisipasi dalam konservasi dan rehabilitasi SD HL. Pengaruh umur petani terhadap keputusan berpartisipasi tidak tampak nyata. Thacher \& al. (1997) dan Zhang dan Flick (2001), misalnya, menemukan bahwa partisipasi petani dalam konservasi dan rehabilitasi SD HL tidak dipengaruhi oleh umur. Sementara itu, Atmis \& al. (2007) melaporkan bahwa umur petani merupakan variabel penting dalam menjelaskan partisipasi petani dalam konservasi dan rehabilitasi SD HL. Petani yang berusia muda cenderung bersedia berpartisipasi dibandingkan dengan petani yang berusia lebih tua. Featherstone dan G oodwin (1993) menemukan hubungan yang kuat antara luas lahan yang dikuasai petani dengan partisipasi petani dalam konservasi dan rehabilitasi SD HL. Petani dengan kepemilikan lahan yang luas cenderung bersedia berpartisipasi dalam proyek konservasi dan rehabilitasi SD HL dibandingkan dengan petani yang memiliki lahan sempit. Salam \& al. (2000), dalam penelitiannya di Bangladesh, mendapatkan temuan bahwa petani-petani yang tidak memiliki pekerjaan off-farm cenderung enggan mengembangkan usaha hutan rakyat pada lahan yang dikuasainya. Hasil penelitian Naik (1997) di India menunjukkan bahwa jumlah anggota keluarga berpengaruh positif terhadap tingkat partisipasi petani dalam konservasi dan rehabilitasi SD HL.

Mengacu pada hasil-hasil penelitian tersebut, maka dapat dirumuskan hipotesa yang menunjukkan hubungan antara beberapa variabel bebas dengan partisipasi petani dalam proyek hutan rakyat untuk mitigasi perubahan iklim. Rumusan hipotesa yang digunakan dalam penelitian ini disajikan pada Tabel 1.

\section{METODE PENELITIAN}

Penelitian ini menggunakan data hasil survei yang dilakukan pada bulan Juni tahun 2010 terhadap 117 orang petani hutan rakyat di Desa Tempurejo, Kecamatan Kalibawang, Kabupaten Wonosobo, Jawa Tengah. Pemilihan lokasi dilakukan secara sengaja dengan mempertimbangkan 3 hal. Pertama, lokasi penelitian termasuk dalam sub das Medono yang merupakan hulu daerah aliran sungai (DAS) Wawar yang mencakup wilayah Kabupaten Wonosobo, Purworejo dan Kebumen sehingga kelestarian kawasan berhutan di hulu DAS akan berdampak pada ketiga kabupaten tersebut. Kedua, D esa Tempurejo termasuk dalam lingkar 2 zona kawasan hijau waduk Wadas Lintang yang berfungsi sebagai pemasok air irigasi lahan-lahan pertanian di Kabupaten Purworejo dan Kebumen. Berdasarkan hasil kajian hidrologi dengan menggunakan perhitungan neraca air, potensi sumber daya air DAS Wawar yang luasnya mencapai 761 $\mathrm{km}^{2}$ dan panjang sungainya sekitar $35,9 \mathrm{~km}$ adalah sebesar 43.590 liter/ detik (Saifudin dan Anshori, 2008). Jika diasumsikan bahwa kebutuhan air irigasi setiap hektar adalah 1 liter/ detik, maka DAS Wawar 
diperkirakan mampu mengairi sawah sekitar 43.590 ha (Saifudin dan Anshori, 2008). Ketiga, usaha hutan rakyat, khususnya hutan rakyat tanaman sengon (Falcataria molucama) telah dikembangkan masyarakat D esa Tempurejo sejak tahun 1980-an (komunikasi pribadi dengan sesepuh D esa Tempurejo).
Pengambilan sampel dilakukan dengan menggunakan metode acak sederhana (simple random sampling method) dan menggunakan daftar petani hutan rakyat sebanyak \pm 700 orang petani hutan rakyat sebagai sampling frame Pengambilan data dilakukan melalui wawancara langsung dengan menggunakan instrumen kuesioner

Tabel 1. D efinisi O perasional Variabel-variabel yang Digunakan dalam Model Empiris

\begin{tabular}{|c|c|c|c|}
\hline Variabel & Satuan & Definisi Operasional & $\begin{array}{c}\text { Korelasi } \\
\text { yang } \\
\text { Diharapkan }\end{array}$ \\
\hline 1. Kesediaan berpartisipasi $\left(\mathrm{y}_{\mathrm{j}}\right)$ & biner & $\begin{array}{l}=1 \text { jika petani bersedia } \\
\text { berpartisipasi, =0 jika } \\
\text { tidak bersedia }\end{array}$ & \\
\hline 2. $\operatorname{Umur}\left(\mathrm{x}_{\mathrm{1i}}\right)$ & tahun & Umur petani & $+/-$ \\
\hline 3. Pendidikan $\left(\mathrm{x}_{2 \mathrm{i}}\right)$ & tahun & $\begin{array}{l}\text { Lamanya waktu yang } \\
\text { digunakan petani untuk } \\
\text { men empuh pendidikan } \\
\text { formal }\end{array}$ & + \\
\hline 4. Pekerjaan Off-fam $\left(\mathrm{x}_{3 \mathrm{i}}\right)$ & biner & $\begin{array}{l}=1 \text { jika petani memiliki } \\
\text { pekerjaan off-farm, } 0= \\
\text { jika tidak memiliki }\end{array}$ & + \\
\hline 5. Jumlah anggota keluarga $\left(\mathrm{x}_{4 \mathrm{i}}\right)$ & orang & $\begin{array}{l}\text { Jumlah anggota rum ah } \\
\text { tan gga yang masih } \\
\text { menjadi tan ggungan } \\
\text { petani }\end{array}$ & - \\
\hline 6. Pengeluaran bulanan keluarga $\left(\mathrm{x}_{5 j}\right)$ & $\begin{array}{l}\text { Rp. } \\
10.000,-\end{array}$ & $\begin{array}{l}\text { Besarnya pengeluaran } \\
\text { bulanan rumah tangga }\end{array}$ & - \\
\hline 7. Pengalaman usaha hutan rakyat $\left(\mathrm{x}_{6 \mathrm{i}}\right)$ & tahun & $\begin{array}{l}\text { Lamanya pengalaman } \\
\text { melakukan usaha hutan } \\
\text { rakyat }\end{array}$ & + \\
\hline $\begin{array}{l}\text { 8. Keikutsertaan dalam kelompok tani } \\
\left(\mathrm{x}_{7 \mathrm{i}}\right)\end{array}$ & biner & $\begin{array}{l}=1 \text { jika petani } \\
\text { merup akan anggota } \\
\text { kelo mpok tani, =0 jika } \\
\text { tidak }\end{array}$ & + \\
\hline 9. Luas lahan yang dikuasai $\left(\mathrm{x}_{8 \mathrm{ii}}\right)$ & hektar & $\begin{array}{l}\text { Luas lahan yang dikuasai } \\
\text { petani dan keluarganya }\end{array}$ & + \\
\hline
\end{tabular}

Sumber: hasil analisis data sekunder 
semi-berstruktur. D ata yang diambil meliputi kesediaan petani untuk berpartisipasi dalam proyek mitigasi perubahan iklim, karakteristik petani dan keluarganya, serta luas lahan yang dikuasai petani. D efinisi operasional masing-masing variabel yang digunakan dalam model empiris disajikan pada Tabel 1. Kesediaan petani berpartisipasi diketahui melalui pemaparan skenario proyek hutan rakyat untuk mitigasi perubahan iklim yang dirumuskan sebagai berikut:

"Dalam rangka mengatasi perubahan iklim pemenintah akan mengduarkan kebijakan pembangunan hutan rakyat lahan milik masyarakat dengan ketentuan bahwa hutan rakyat tersebut tidak boleh ditebang atau dialihfungsikan untuk keperluan lain dalam jangka waktu 15 tahun dan hanus dikelola sesuai dengan kaidah-kaidah silvikultur sesuai denganketentuan-ketentuanyangdittapkan deh pemerintah. Keikutsertaan petani bersifat sukarda dan pada akhirmasa proyk (15 tahun) petani dapat memiliki selunh hasil hutan rakyat yang dikembangkan di atas lahan miliknya. A tas kesediaan petani berpartisipasi dalam proydk terseaut, pemeintah akan memberikan kompensasi yang besamya akan ditentukan kemudian sesuai dengan kesepakatan dengan ptani dan pihak-pihak yang tekkait.

Jika kebijakan tersebut diterapkan, apakah Anda bersedia berpartisipasi? Ya/ Tidak"

Analisis data meliputi analisis data deskriptif dan inferensi. Analisis data deskriptif dilakukan dengan menggunakan metode statistika deskriptif yang meliputi perhitungan frekuensi dan rerata sampel yang disajikan dalam bentuk tabel. Analisis inferensi dilakukan dengan menggunakan model empiris yang galatnya diasumsikan berdistribusi logistik sehingga dapat diestimasi dengan menggunakan metode logit. Model empiris yang digunakan dalam penelitian ini adalah sebagai berikut: $y_{i}^{*}=\alpha+\sum_{j=1}^{8} \beta_{j} x_{i j}+\varepsilon_{i}$

$y^{*}$ merupakan variabel laten atau tersembunyi. Mengacu pada kerangka konseptual bahwa seorang petani $i$ akan berpartisipasi jika selisih antara utilitas yang dia peroleh dari berpartisipasi dan tidak berpartisipasi melampaui ambang batas tertentu, misalnya 0 , maka sebagai konsekuensinya adalah bahwa data hasil survei akan menunjukkan $y_{i}=1$ jika dan hanya jika $y_{i}^{*}>0$ dan $y_{i}=0$ jika sebaliknya. D engan mengacu pada persamaan (2), maka keputusan petani untuk berpartisipasi dapat dituliskan sebagai berikut:

$\operatorname{Pr}\left(y_{i}=1 \mid \mathbf{x}\right)=\Psi\left(y_{i}^{*}\right)$

dalam hal ini $\Psi($.$) adalah cdf.$

Metode estimasi logit mengasumsikan bahwa cdf berdistribusi logistik sehingga dapat dituliskan sebagai berikut:

$$
\operatorname{Pr}\left(y_{i}=1 \mid \mathbf{x}\right)=\frac{\exp \left(\alpha+\sum_{j=1}^{8} \beta_{j} x_{j i}\right)}{1+\exp \left(\alpha+\sum_{j=1}^{8} \beta_{j} x_{j i}\right)}
$$

Efek marjinal variabel-variabel bebas terhadap partisipasi petani $(y)$ merupakan hasil dari kombinasi 2 faktor, yaitu efek variabel $x_{j}$ terhadap variabel laten $y_{i}^{*}$ dan turunan (derivasi) cdf yang dievaluasi pada $y_{i}^{*}$. D engan demikian, efek marjinal variabel $x_{j}$ terhadap $y$ adalah

$$
\begin{aligned}
\frac{\partial \operatorname{Pr}(y=1 \mid \mathbf{x})}{\partial x_{j}} & =\frac{\partial \operatorname{Pr}(y=1 \mid \mathbf{x})}{\partial(z)} \cdot \frac{\partial(z)}{\partial x_{j}} \\
& =\Psi^{\prime}(z) \cdot \beta_{j}=\psi(z) \cdot \beta_{j}
\end{aligned}
$$


Dalam hal ini, $\psi$ adalah probability density function (pdf) dari distribusi logistik yang dapat dirumuskan sebagai:

$$
\psi(z)=\frac{\exp (z)}{\{1+\exp (z)\}^{2}} \text { dan } z=\alpha+\sum_{j=1}^{8} \beta_{j} x_{j}
$$

\section{HASIL DAN PEMBAHASAN}

\section{Gambaran Umum Petani dan Usaha Hutan Rakyat}

Desa Tempurejo merupakan bagian dari wilayah administrasi Kabupaten Wonosobo. Letaknya $\pm 25 \mathrm{~km}$ sebelah selatan ibukota kabupaten dan merupakan salah satu sentra produksi kayu rakyat, khususnya kayu sengon (Falcataria moluccana). Luas wilayah desa adalah $\pm 773,73$ ha dengan topografi berbukit. Rerata ketinggian lahan adalah antara 600 sampai dengan 800 meter di atas permukaan laut. Dari data statistik tahun 2009, penggunaan lahan untuk usahatani lahan kering mencapai 633,605 ha atau $81,89 \%$ dari luas wilayah desa. Penggunaan lahan lainnya adalah areal persawahan seluas 49,6 ha $(6,41 \%)$, pekarangan seluas 28,78 ha $(3,72 \%)$, kolam perikanan seluas 0,5 ha $(0,06 \%)$, pemukiman dan fasilitas umum mencapai 21,45 ha (2,77\%). Selain itu, wilayah Desa Tempurejo juga mencakup kawasan hutan negara pangkuan Perum Perhutani yang luasnya mencapai 39,8 ha. Jumlah penduduk desa pada tahun 2009 adalah 3.921 orang dan 1.101 orang di antaranya bekerja di sektor pertanian, dengan perincian 702 orang bekerja sebagai petani dan 399 orang bekerja sebagai buruh tani (Badan Pusat Statistik Kabupaten Wonosobo, 2009).

Pengelolaan hutan rakyat secara semi komersial oleh masyarakat D esa Tempurejo mulai terjadi sejak tahun 1980-an.
Sebelumnya, hasil hutan rakyat, terutama kayu, umumnya dimanfaatkan untuk memenuhi kebutuhan subsistensi rumah tangga petani, seperti kayu bakar, kayu bangunan dan pertukangan. Penanaman tanaman berkayu/ kehutanan pada lahan milik petani, seperti sengon, pada saat itu lebih ditujukan sebagai tanaman naungan pada usaha tani kopi daripada untuk tujuan komersial. Semakin berkembangnya industri pengolahan kayu, khususnya kayu sengon, menyebabkan peningkatan permintaan kayu. Sebagai akibatnya, pasar kayu rakyat menjadi berkembang dan masyarakat dapat dengan mudah memasarkan hasil kayu hutan rakyat ke industri pengolahan kayu melalui perantaraan pengempul atau tengkulak kayu. Perkembangan harga yang terus meningkat dari tahun ke tahun harga kayu menjadi insentif bagi petani untuk mengusahakan hutan rakyat secara semi komersial. Perlahan, hasil kayu hutan rakyat menjadi salah satu sumber pendapatan utama bagi sebagian besar masyarakat D esa Tempurejo.

Hutan rakyat umumnya diusahakan dengan pola campuran (pdyaiture) dengan dominasi tanaman sengon dan menggunakan sistem wanatani (agroforestry). Sebagai tanaman bawah tegakan adalah kopi, cabe, kapulaga dan talas. Tanaman bawah tegakan biasanya merupakan salah satu sumber pendapatan utama sebelum tanaman kayu bisa dipanen. Petani biasanya memanen tanaman kayu ketika umurnya telah mencapai 5 tahun atau lebih. Hasil survei menunjukkan bahwa terdapat 3 sistem penebangan kayu hutan rakyat yang berkembang di masyarakat, yaitu sistem tebang habis, sistem tebang pilih dan sistem tebang butuh. Sebagian besar petani responden (73\%) menerapkan sistem tebang butuh, sementara sisanya menerapkan sistem tebang pilih (15\%) dan 
sistem tebang habis (12\%). Perbedaan mendasar antara sistem tebang pilih dan sistem tebang butuh terletak pada kriteria yang digunakan petani untuk menetapkan jumlah tegakan yang ditebang. Pada sistem tebang butuh kriteria yang digunakan adalah besarnya kebutuhan keuangan yang menjadi beban petani, sedangkan kriteria yang digunakan dalam sistem tebang pilih adalah umur dan volume kayu yang dicerminkan dari diameter dan tinggi tegakan.

Karakteristik umum petani hutan rakyat di D esa Tempurejo secara rerata adalah berumur lebih dari 40 tahun, berpendidikan setingkat sekolah dasar (SD), berpengalaman usaha hutan rakyat lebih dari 17 tahun dan lebih dari $40 \%$ diantaranya memiliki pekerjaan off-farm seperti pedagang, buruh tani dan tukang ojek. Jumlah rerata anggota rumah tangga petani adalah 4 atau 5 orang. Pengeluaran rerata bulanan setiap rumah tangga adalah berkisar antara lebih dari Rp. 860.000,- sampai dengan kurang dari Rp. 880.000,-. Setiap rumah tangga petani responden secara rerata menguasai lahan seluas lebih dari 0,8 ha (Tabel 2).

Hasil survei menunjukkan bahwa dari 117 petani hutan rakyat yang menjadi responden, 97 orang menyatakan bersedia berpartisipasi dan sisanya sebanyak 20 orang menolak berpartisipasi dalam proyek hutan rakyat untuk mitigasi perubahaan iklim. Perbandingan antara karakteristik petani yang tidak bersedia dengan yang bersedia berpartisipasi dalam proyek hutan rakyat untuk mitigasi perubahan iklim tidak menunjukkan perbedaan yang mencolok, kecuali untuk variabel pendidikan $\left(\mathrm{x}_{2}\right)$, jumlah anggota keluarga $\left(\mathrm{x}_{4}\right)$ dan pengalaman usaha hutan rakyat $\left(\mathrm{x}_{6}\right)$. Petani yang tidak bersedia berpartisipasi secara rerata memiliki tingkat pendidikan yang lebih rendah, jumlah anggota keluarga yang lebih banyak dan berpengalaman usaha hutan rakyat yang lebih lama dibandingkan dengan petani yang bersedia berpartisipasi.

Tabel 2. Statistik D eskriptif Petani Hutan Rakyat Desa Tempurejo, Kabupaten Wonosobo

\begin{tabular}{lrrrrr}
\hline \multicolumn{1}{c}{ Variabel } & \multicolumn{2}{c}{ Menolak } & \multicolumn{2}{c}{ Bersedia } & \\
& Rerata & $\begin{array}{c}\text { Standar } \\
\text { Deviasi }\end{array}$ & Rerata & $\begin{array}{c}\text { Standar } \\
\text { Deviasi }\end{array}$ & Uji t \\
& 45,350 & 13,402 & 42,917 & 9,111 & \\
\hline 1. Umur $\left(\mathrm{x}_{1}\right)$ & 5,100 & 2,337 & 6,464 & 2,282 & $* *$ \\
2. Pendidikan $\left(\mathrm{x}_{2}\right)$ & 0,400 & 0,503 & 0,495 & 0,503 & \\
3. Pekerjaan O ff-farm $\left(\mathrm{x}_{3}\right)$ & 4,500 & 1,277 & 3,907 & 1,259 & $* *$ \\
4. Jumlah anggota keluarga $\left(\mathrm{x}_{4}\right)$ & 86,186 & 32,247 & 87,825 & 40,737 & \\
5. Pengeluaran bulanan keluarga $\left(\mathrm{x}_{5}\right)$ & 22,950 & 12,775 & 17,505 & 8,729 & $* *$ \\
6. Pengalaman usah a hutan rakyat $\left(\mathrm{x}_{6}\right)$ & 0,550 & 0,510 & 0,567 & 0,498 & \\
7. Keikutsertaan dalam kelompok tani $\left(\mathrm{x}_{7}\right)$ & 0,861 & 0,681 & 0,877 & 0,672 & \\
8. Luas lahan yang dikuasai $\left(\mathrm{x}_{8}\right)$ & & & & &
\end{tabular}

Sumber: hasil analisis

Keterangan: ** berturut-turut mengindikasikan tingkat signifikansi 5\% 
Faktor-Faktor yang Berpengaruh terhadap Partisipasi Petani

Hasil estimasi dengan metode logit terhadap model empiris disajikan pada Tabel 3. Sebelumnya, model tersebut telah melewati uji spesifikasi model yang meliputi uji multikolinieritas, uji kesalahan spesifikasi model dan uji signifikansi model dengan menggunakan uji G. Hasil uji multikolinieritas menunjukkan bahwa nilai VIF masing-masing variabel dan nilai rerata VIF keduanya mendekati 1. D emikian juga dengan nilai tderameyang juga mendekati 1. Sementara itu, uji spesifikasi model dilakukan dengan menggunakan link test. Uji ini dapat mengindikasikan bahwa jika spesifikasi suatu model telah benar atau mendekati kebenaran, maka dengan sendirinya penambahan variabel lain tidak akan memperbaiki kualitas model yang dibangun kecuali kebetulan saja. Hasil uji link testmenunjukkan bahwa model empiris yang digunakan dalam penelitian ini telah benar atau setidaknya mendekati kebenaran karena nilai_hat berbeda nyata dari 0 pada tingkat signifikansi $5 \%$. Uji signifikansi model dengan menggunakan uji G mengindikasikan bahwa model empiris yang diestimasi secara statistik dapat diterima pada tingkat signifikansi $5 \%$. Nilai ko efisien Pseudo- $\mathrm{R}^{2}$ adalah 0,177 . Greene (2003) menyatakan bahwa nilai koefisien determinasi sebesar 0.177 untuk penelitian empiris ilmu sosial dengan data aosssetion masih dapat diterima. Secara umum model empiris yang digunakan dalam penelitian ini mampu memprediksi data hasil survei dengan ketepatan sebesar $85.47 \%$.

Hasil estimasi menunjukkan bahwa terdapat 4 variabel bebas yang nilai koefisiennya secara statistik berbeda nyata dari nol atau berpengaruh terhadap kecenderungan petani untuk berpartisipasi.

Tabel 3. Hasil Estimasi Model Empiris dengan Metode Logt

\begin{tabular}{lccr}
\hline \multicolumn{1}{c}{ Variable } & Koefisien & $\begin{array}{c}\text { Standar } \\
\text { Error }\end{array}$ & $\begin{array}{c}\text { Efek } \\
\text { Marjinal }\end{array}$ \\
\hline 1. Umur $\left(\mathrm{x}_{1}\right)$ & $0,105 * *$ & 0,051 & 0,010 \\
2. Pendidikan $\left(\mathrm{x}_{2}\right)$ & $0,493 * *$ & 0,176 & 0,048 \\
3. Pekerjaan Off-fam $\left(\mathrm{x}_{3}\right)$ & $-0,168$ & 0,590 & $-0,016$ \\
4. Jumlah anggota keluarga $\left(\mathrm{x}_{4}\right)$ & $-0,615 * *$ & 0,256 & $-0,060$ \\
5. Pengeluaran bulanan keluarga $\left(\mathrm{x}_{5}\right)$ & 0,003 & 0,008 & 0,0003 \\
6. Pengalaman usaha hutan rakyat $\left(\mathrm{x}_{6}\right)$ & $-0,104 * *$ & 0,049 & $-0,010$ \\
7. Keikutsertaan dalam kelompok tani $\left(\mathrm{x}_{7}\right)$ & 0,119 & 0,580 & 0,012 \\
8. Luas lahan yang dikuasai $\left(\mathrm{x}_{8}\right)$ & 0,204 & 0,456 & 0,020 \\
9. Konstanta $(\alpha)$ & $-1,555$ & 2,035 & \\
& & & \\
Loglikelihood & $-44,028$ & & \\
LR $\chi^{2}(8)$ & $18,97 * *$ & & \\
Pseudo $\mathrm{R}^{2}$ & 0,177 & & \\
\hline Sul & & & \\
\hline
\end{tabular}

Sumber: hasil analisis

Keterangan: ${ }^{* *},{ }^{* * *}$ berturut-turut mengindikasikan tingkat signifikansi $5 \%$ dan $1 \%$ 
Variabel-variabel tersebut adalah umur, pendidikan, jumlah anggota keluarga dan pengalaman usaha hutan rakyat. Nilai koefisien variabel umur $\left(\mathrm{x}_{1}\right)$ adalah sebesar 0,105 dan berbeda nyata dari nol pada tingkat signifikansi $5 \%$. Sementara itu, nilai efek marjinal variabel $\mathrm{x}_{1}$ adalah 0,010 . Interpretasinya adalah bahwa peningkatan umur petani akan cenderung meningkatkan peluang petani untuk berpartisipasi dalam proyek hutan rakyat untuk mitigasi perubahan iklim sebesar 1\%, cteis paribus

Nilai koefisien variabel pendidikan $\left(\mathrm{x}_{2}\right)$ adalah sebesar 0,493 dan secara statistik berbeda nyata dari nol pada tingkat signifikansi $1 \%$. Tanda positif koefisien variabel $\mathrm{x}_{2}$ sesuai dengan hipotesa yang dirumuskan pada Tabel 2. Dengan memperhatikan nilai efek marjinal variabel $\mathrm{x}_{2}$ sebesar 0,048 , maka penambahan pendidikan petani selama 1 tahun dapat meningkatkan peluang berpartisipasi petani sebesar 4,8\%, cteris paribus Temuan ini sejalan dengan hasil dari penelitianpenelitian terdahulu (misalnya: Lise, 2000; G lendinning \& al., 2001; O wubah \& al, 2001) tentang partisipasi petani dalam kegiatan reboisasi dan rehabilitasi SD HL di berbagai lokasi. Namun demikian, implikasi kebijakan dari temuan ini perlu disikapi secara hati-hati. Dengan mempertimbangkan rerata umur petani responden lebih dari 40 tahun (Tabel 2), maka peningkatan pendidikan petani melalui pendidikan formal barangkali bukanlah merupakan opsi kebijakan yang tepat, meskipun hal itu memungkinkan. O psi kebijakan yang masih memungkinkan adalah dengan meningkatkan pengetahuan petani tentang perubahan iklim melalui program-program penyuluhan, baik dalam bentuk penyuluhan kehutanan konvensional maupun sekolah lapang iklim seperti yang telah dikembangkan di Kabupaten Indramayu dan Gunung Kidul hasil kerjasama antara Institut Pertanian Bogor (IPB), Badan Meteorologi, Klimatologi dan G eofisika (BMKG), the Asian Disaster Pre pareechess Centerdan Kementerian Pertanian.

Nilai koefisien variabel jumlah anggota keluarga $\left(\mathrm{x}_{4}\right)$ dan pengalaman usaha hutan rakyat $\left(\mathrm{x}_{5}\right)$ secara statistik berbeda nyata dari nol pada tingkat signifikansi $5 \%$ dan bertanda negatif. Berdasarkan nilai efek marjinal variabel $\mathrm{x}_{4}$ dapat diinterpretasikan bahwa peningkatan jumlah anggota keluarga sebanyak 1 orang akan menurunkan peluang petani untuk berpartisipasi sebesar 6\%, cteis paribus Sementara itu, interpretasi yang dapat diberikan untuk variabel $\mathrm{x}_{5}$ adalah bahwa peningkatan pengalaman usaha hutan rakyat selama 1 tahun akan cenderung menurunkan peluang petani untuk berpartisipasi sebesar $1 \%$, cteis paribus

Tanda negatif nilai ko efisien variabel $\mathrm{x}_{4}$ dan $\mathrm{x}_{5}$ tidak sesuai dengan yang dihipotesakan pada Tabel 1. Temuan ini barangkali terkait dengan ketergantungan ekonomi sebagian besar rumah tangga petani responden terhadap pendapatan yang berasal dari usaha hutan rakyat. Semakin banyaknya jumlah anggota keluarga berimplikasi pada membesarnya anggaran rumah tangga. Bagi rumah tangga yang menggantungkan sepenuhnya sumber pendapatan rumah tangga dari usaha hutan rakyat tentu akan menerapkan sistem pengelolaan usaha hutan rakyat yang mampu menjamin kontinuitas aliran pendapatan bagi rumah tangganya. Apalagi jika akses terhadap sumber pendapatan di luar usaha hutan rakyat atau kredit masih sangat sulit dijangkau oleh sebagian keluarga petani seperti yang terjadi di D esa Tempurejo. Interupsi aliran pendapatan dapat berdampak pada stabilitas ekonomi keluarga. Partisipasi petani dalam proyek hutan rakyat untuk mitigasi perubahan iklim dapat berdampak perubahan sistem 
pengelolaan hutan rakyat yang selama ini diterapkan petani. Meskipun ada kompensasi yang akan diberikan, petani akan tetap memperhitungkan risiko kegagalan berdasarkan pengalamannya dalam melakukan usaha hutan rakyat. Petani yang telah lama berpengalaman dalam usaha hutan rakyat akan lebih memperhitungkan risiko keikutsertaannya dalam proyek hutan rakyat dibandingkan petani yang kurang berpengalaman dan oleh karenanya akan lebih berhati-hati dalam memutuskan untuk berpartisipasi sebelum ada kepastian atau jaminan bahwa proyek tersebut tidak mengganggu stabilitas ekonomi rumah tangganya.

\section{KESIMPULAN DAN SARAN Kesimpulan}

(1) Hasil analisis deskriptif menunjukkan bahwa terdapat 97 orang petani atau $82,91 \%$ responden yang menyatakan bersedia berpartisipasi dan sisanya menyatakan tidak bersedia ber-partsipasi dalam proyek hutan rakyat untuk mitigasi perubahan iklim; (2) kecenderungan petani dalam ber-partisipasi secara statistik dipengaruhi oleh umur, pendidikan, jumlah anggota keluarga dan pengalaman usaha hutan rakyat. Variabel umur dan pendidikan berpengaruh positif terhadap kecenderungan petani untuk berpartisipasi; masingmasing sebesar $1 \%$ dan $4.8 \%$. Sementara itu, variabel jumlah anggota keluarga dan pengalaman usaha hutan rakyat berpengaruh negatif terhadap kecen-derungan petani untuk berpartisipasi. Temuan ini terkait dengan sistem pengelolaan hutan rakyat yang berkembang di masyarakat D esa Tempurejo. Usaha hutan rakyat umumnya merupakan sumber pendapatan utama bagi sebagian besar rumah tangga tani. Karena proyek hutan rakyat yang diskenariokan dalam penelitian ini kemungkinan besar akan berdampak pada perubahan sistem pengelolaan hutan rakyat, khususnya intensitas pemeliharaan tegakan dan masa jeda panen hasil kayu yang mencapai 15 tahun, maka sebagian petani yang memiliki jumlah anggota keluarga yang besar dan berpengalaman dalam usaha hutan rakyat akan cenderung enggan berpartisipasi, kecuali besarnya kompensasi yang diberikan mampu menjamin stabilitas ekonomi rumah tangga mereka.

\section{Saran}

(1) Hasil penelitian ini menunjukkan bahwa variabel pendidikan memiliki pengaruh positif terhadap partisipasi petani. Implikasi kebijakan dari temuan ini adalah bahwa pemerintah perlu meningkatkan pengetahuan petani terutama tentang perubahan iklim. Salah satu strategi yang dapat dilakukan adalah dengan mengembang-kan program-program penyuluhan perubahan iklim sehingga petani mendapat pengetahuan yang cukup tentang hal tersebut serta dapat berkontribusi dalam mitigasi perubah-an iklim dan mampu beradaptasi terhadap dampak negatif perubahan iklim; (2) perubahan iklim adalah suatu hal yang sangat kompleks dan oleh karena itu perlu dikembangkan program-program penyuluhan sedemikian rupa sehingga petani yang sebagian besar berpendidik-an sekolah dasar dapat menangkap pesan-pesan tentang mitigasi dan adaptasi perubahan iklim secara tepat dan benar. Sekolah Lapang Perubahan Iklim yang dikembangkan dari Sekolah Lapang Pengendalian Hama Terpadu tampaknya dapat dikembangkan lebih lanjut di kawasan sentra produksi kayu rakyat seperti Desa Tempurejo; (3) proyek-proyek hutan rakyat untuk mitigasi perubahan iklim sebaiknya dirancang dengan memperhatikan sistem pengelolaan hutan rakyat yang telah 
berkembang di masyarakat. Hubungan antara sistem ekonomi rumah tangga tani dan sistem pe-ngelolaan hutan rakyat perlu untuk diteliti lebih lanjut untuk mendapatkan pemahaman yang komprehensif dampak proyek hutan rakyat untuk mitigasi perubahan iklim terhadap stabilitas ekonomi rumah tangga tani; (4) analisis yang dilakukan dalam penelitian ini berdasarkan data cosssettion yang diambil pada satu waktu tertentu sehingga tidak mencakup aspek dinamis pengambilan keputusan.

\section{DAFTAR PUSTAKA}

Atmis, E., I. Dasdemir, W. Lise, and O. Yildiran. (2007). Factors affecting women's participation in forestry in Turkey. Ecologial Economics 60 (4): 787-796

Balai Pemantapan Kawasan Hutan (BPKH) Wilayah XI Jawa-Madura dan Multistakeholder Forestry Programme. (2009). Strateg Pengembengan Pengddaan dan Arahan Kdajakan: Hutan Rakyat di Pulau Jama D epartemen Kehutanan, Jakarta, 61pp.

Badan Pusat Statistik (BPS) Kabupaten Wonosobo. (2009). Wonosobo dalam Angka Tahun 2009. BPS, Wonosobo.

D epartemen Kehutanan. (2009). Statistik Kehutanan 2008 D epartemen Kehutanan, Jakarta.

Featherstone, A. M. and B. K. Goodwin. (1993). Factors Influencing a Farmer's D ecision to Invest in Long-Term Conservation Improvements. LandEconomics 69 (1): 67-81.

Glendinning, A., J. Mahapatra and C. P. Mitchell. (2001). Modes of communication and effectives of agroforestry extension in eastern India. Human Eøogy, 29 (3): 283-305.

Gombe, A. (1985). People's Participation and Rural D evelopment. In (K.J.B. Keregero, H.K.L. Mahimbo and A.J.L. Lwelamila, eds) Popular Partiapation in Planning Rural Dedqpment. pp. 10-16, Institute of Rural D evelopment Planning, D odoma, Tanzania.

G reene, W. (2003). Econmenic Analysis $5^{\text {th }}$ edition Englewood Cliffs: Prentice Hal.

Hayati, S. (2010) Partisipasi Masyarakat dalam Pengembangan Ekowisata di Pangandaran Jawa Barat. FonumGeogafi. Vol. 24, No. 1, pp. 12-27.

Lise, W., (2000). Factors influencing peoples' participation in forest management in India. Ecogogal Econmics 34 (3): 379-392.

Naik. G. (1997). Joint Forest Management: Factors Influencing Household Participation. Econmic and Pditical Weekly, 32 (48): 3084-3089.

O wubah, C., D . C. Lemaster, J. M. Bowker and J. G. Lee. (2001). Forest tenure systems 
and sustainable forest management: the case of G hana. Forest Ecologial Management, 149 (1-3): 253-264.

Portes, A., (1971). Political primitivism differential socialization and lower-class radicalism. American Sodidogial Reviev 36 (5): 820-835.

Rimbawanto, A. (2008). Pemuliaan Tanaman dan Ketahanan Penyakit pada Sengon. Makalah disampaikan pada Workshop Penanggulangan Serangan Karat Puru pada Tanaman Sengon, 19 November 2008, Balai Besar Penelitian Bioteknologi dan Pemuliaan Tanaman Hutan, Yogyakarta.

Saifudin dan C. Anshori. (2008). Potensi Sumber D aya Air D AS Wawar untuk Perencanaan Irigasi Kabupaten Kebumen. Prosiding Pemaparan Hasil Penelitian Puslit Geoteknologi 2008: Peran Riset G eoteknologi dalam Mendukung Pembangunan Berwawasan Lingkungan. Bandung.

Salam, M.A., T. Noguchi and M. Koike. (2000). Understanding why farmers plant trees in the homestead agroforestry in Bangladesh. Agroforetry System 50(1): 77-93.

Thacher, T., D.R. Lee and J.W. Schelhas. (1997). Farmer participation in reforestation incentive programs in Costa Rica. Aguforestry System 35(3): 269-289.

Zhang, D . and W. Flick. (2001). Sticks, carrots, and reforestation investment. LandEconomics 77(3): 443-456. 